\title{
Experiment and Institutionalization: Clean Elections in New Jersey
}

\author{
Michael J. BRogAN
}

\begin{abstract}
There is not a general consensus among scholars about whether public campaign funding initiatives increase electoral competitiveness. U.S. focused research has found the effects of Clean Election (CE) funding present mixed outcomes (Mayer and Wood 1995; GAO 2003; Mayer, Werner, and Williams 2004; Werner and Mayer 2007) On the one hand, research has found that Clean Election funding creates more competitive elections (Bardwell 2002; Mayer, Werner, and Williams 2004). While on the other, Clean Election funding scholars have found that public funding of state legislative candidates has not caused elections to become more competitive (Mayer and Wood 1995; GAO 2003). One reason for the difference in the research literature is likely a result of the program being in its early years of implementation in the U.S. This paper provides a new technique for estimating the short-term and long-range effects of the program by experimenting on the New Jersey case which is designed to cope with limited data. It accomplishes this by creating simulated elections that are based on the lessons-learned in Arizona and Maine, as well as on structural constraints present in New Jersey. The experiment's results confirm the impact of Clean Elections is mixed: The impact of Clean Election funding increases intra-party competition but does not increase inter-party competition. Nevertheless, while the impact of Clean Elections does show some encouraging signs for proponents of electoral reform, it is unlikely to transform the electoral landscape by making elections more competitive.
\end{abstract}

KEYWORDS: • public campaign funding $\bullet$ clean elections $\bullet$ political parties • elections $\bullet$ New Jersey $\bullet$ United States

CORRESPONDENCE AdDRESS: Michael J. Brogan, The Graduate Center, The City University of New York, 365 5th Ave., New York, NY 10016, United States, e-mail: mbrogan@rider.eu. 
Though there has been considerable debate in the literature on the effectiveness of public funding on elections, there has not been a general consensus about whether Clean Election (CE) campaign funding initiatives increase electoral competitiveness. Findings on Clean Election funding in the U.S. present mixed outcomes (Mayer and Wood 1995; GAO 2003; Mayer, Werner, and Williams 2004; Werner and Mayer 2007). On the one hand, research has found that Clean Election funding creates more competitive elections (Bardwell 2002; Mayer, Werner, and Williams 2004). While on the other, Clean Election funding scholars have found that public funding of state legislative candidates has not caused elections to become more competitive following the program's introduction (GAO 2003; Mayer and Wood 1995). ${ }^{1}$ One reason for the program's mixed results is likely a result of the program being in its early years of implementation. Further analysis of its impact is required to assess both the long-term and short-term effects on state-level elections. Further analysis of its impact is required to assess both the long-term and short-term effects on U.S. state-level elections. This paper provides a new technique for estimating the short-term and long-range effects of the program by experimenting on the New Jersey case which is designed to cope with the problem of limited data.

Further, this paper adds to this debate by analyzing the effects of Clean Election funding on primary and general election contests in New Jersey state legislative elections by comparing it to state legislative election contests in Arizona and Maine. Of primary importance for this experiment is to assess if Clean Election funding increases inter-party and intra-party competition. To do this, the paper analyzes overall party performance during general elections (inter-party), as well as if there are changes in the number of primary elections (intra-party) that are contested in state legislative contests for New Jersey controlling for the effects of current knowledge and constraints provided from these same races in Arizona and Maine from 1990 to 2007. The experiment's results are derived from a series of simulated elections based on the New Jersey sample that are derived on the "lessons learned" in Maine and Arizona in order to evaluate the expected impact of Clean Election funding programs on New Jersey elections.

The paper consists of three sections. The first section provides a brief overview of Clean Elections. The second defines the causal model. The third estimates and presents the results of the simulation. The last section analyses the experiment's results and compares them to the current literature on Clean Elections.

\section{A Brief Overview of Clean Election Funding}

Clean Election funding initiatives in the U.S. are an outgrowth of the historical push for campaign election reform (Brickner and Mueller 2008; GAO 2003). The goal of the program is to reduce the role of private money for public office as a 
means to limit the influence of these donors on elected officials. Typically the program works as a means to supplement private fundraising efforts by candidates where awards are adjusted during the campaign in order to reduce any financial benefit to one candidate over another based on fundraising activities (Brogan and Mendilow 2009).

The Clean Elections program is broadly defined as a comprehensive public funding scheme of political campaigns that establishes a spending ceiling for candidates. To qualify for the program, participating candidates must meet a series of requirements in order to receive public funding. These requirements include: an official declaration that candidates will participate in the program; candidates must raise a required amount of seed money ${ }^{2}$; and candidates must meet qualifying contribution limits ${ }^{3}$ which are set separately by each state (Brickner and Mueller 2008). Funding allocations for program participation range from a variety of formulas that include: percentage dollar matches that are adjusted for inflation; absolute spending ceilings; or are based on an average cost of similar contests over the previous two election cycles. ${ }^{4}$

Proponents of the Clean Elections program argue that public funding encourages likely candidates to participate in the electoral process because it reduces the fundraising barrier which is a likely deterrent for individuals running for office (Mayer, Werner, and Williams 2004). Furthermore, proponents claim an additional benefit of Clean Elections is that the program is likely to cause elections to become more competitive (Phelps 2004; Werner and Mayer 2007). Lastly, supporters of Clean Election funding exert that public campaigns reduce the amount of influence private individuals and groups have on campaigns (Saloye-Kaye 2007).

While critics of the program contend that any benefit accrued from Clean Election funding is likely to be "muted by other factors" within the electoral environment (Brogan and Mendilow 2009: 5). Because the effects of exogenous factors diminish the influence of Clean Elections on electoral outcomes, this results in a decrease in the likelihood of prospective candidates running for public office. Critics also claim the outcome of the program has not resulted in making campaigns more competitive, rather the program diminishes the role of challengers because of advantages afforded to incumbent office holders (Mayer and Wood 1995). In fact, incumbents are likely to spend on average approximately " $2 / 3$ rds of the challenger's spending" resulting in challengers having to match or outspend incumbents in order to win the seat. (Jacobson 2009: 98). Thus, this line of reasoning exerts an unintended consequence of Clean Election funding. That is, it makes it harder, not easier, for challengers to compete with incumbents (Kousser and LaRaja 2002). Lastly, critics point out that public funding schemes create a cartel system where parties are "absorbed by the state" creating a relationship where parties are institutionalized, thus removing the direct effects of constituents' influence in the electoral process (Katz and Mair 1995: 16). ${ }^{5}$ 
Though Clean Election funding in New Jersey has been implemented on a pilot basis in 2005 and 2007, it does nevertheless, provide a unique test case to compare to Arizona and Maine. Though an exhaustive discussion of the similarities and differences of the states, as well as the limitations of comparing them to each other is beyond the scope of this paper, I would like to address a few aspects of the New Jersey election process which makes it a prime case in which to compare it to two states that have actively engaged in Clean Election funding since 2000. ${ }^{6}$ Namely the state's legislative elections are held during off-years as a means to offset national pressures which tend to influence election outcomes. New Jersey has a very competitive electoral environment that is based on the relative vibrancy of the two major parties interacting within the state. The Clean Election pilot program of 2005 and 2007 in New Jersey was based on similar framework for the program that was implemented in Maine and Arizona. ${ }^{7}$ The state does not have term limits, as is the case in Maine and Arizona, which allows the analysis to examine incumbent longevity as a function of the program's implementation. Lastly, the election of multimember districts for the lower house provides a good comparison to Arizona which uses a similar scheme.

\section{Defining the Model}

The research question addressed in this paper analyzes whether Clean Election funding increases electoral competitiveness in New Jersey state legislative elections. It does this from the lessons-learned from implementing this program in Arizona and Maine. The paper experiments with various scenarios that account for the short-term and long-term effects of CE on New Jersey to assess the program's impact on inter-party and intra-party competition. To do this, the model develops equations based on the Maine and Arizona cases. The equations are used to conduct multiple simulations generated from the New Jersey sample in order to estimate the impact of Clean Election funding on elections in the state.

The experiment is based on the following rationale: (1) It controls for a series of state-level, district-level, and national-level factors on state legislative elections; (2) It accounts for uncertainty as a result of candidate factors, scandals, national events, or changes in the electorate that need to be included in the estimations; (3) It requires an evaluation of the independent variables and unknown variables in order to assess their effects on past elections in Maine and Arizona in order to estimate the "predicted" effects of CE funding on New Jersey's electoral environment. The simulation, therefore, provides a new approach to estimating the effects of CE funding on elections which can be applied to other states considering this policy. This is because it provides a mechanism that can generate a distribution of possible outcomes for elections on the whole as a result of the program.

A key factor in conducting this experiment is measuring uncertainty. The first way to do this is to generate normally distributed random variables and then multiply 
them to the initial model's errors that were found in Arizona and Maine; these errors are specifically applied to New Jersey. Second, I randomly assign the number of Clean Election candidates who run in a specific contest based on established variation patterns of participation in Arizona and Maine. Once this process is completed, I add uncertainty into the experiment separately in order to estimate the predicted percent of the vote that the Democratic and Republican parties would get in any district for either the lower or upper chamber in New Jersey based on the program. After this process defines the equations' estimates, I am able to classify electoral outcomes as either won or lost by the majority or minority party. For intraparty experiments, the process is the same except that I classify primary elections as the probability of one additional candidate running in the contest.

The causal model designed for this experiment estimates likely changes from the status quo as a result of the implementation of Clean Election funding which is based on current constraints and knowledge of previous elections held in two states that have implemented the program since 2000. To specify the causal model, I use the following equation:

$$
Y=a+B_{k} X_{k}+e
$$

Where $Y$ represents percentage of the total vote share in a district received by all Democratic or Republican candidates during a given election.

Where $a$ represents the model's constant

Where $B_{k}$ represents the slope of all parameters used in the model.

Where $X_{k}$ is the observed value of the independent parameters for the $i$ th case. used to explain variation in the dependent variable

Where $e$ represents uncertainty within the model's estimates.

The model's constant serves as the expected baseline for the simulation. It is equal to the mean of the dependent variable. I define this as:

$$
a=Y-b \bar{X}
$$

The model's parameters specify the lessons-learned in Maine and Arizona that will be applied to New Jersey. The parameters, therefore, are estimated based on the ratio of the co-variation of the model's independent variables to the variation of each of the model's independent variables. This allows for "netting out" the effects of one independent variable while controlling for all other variables included in the estimations. I define this as: 


$$
b=\frac{\sum \frac{\left(x-\overline{x_{i}}\right)\left(y-\overline{y_{i}}\right)}{n}}{\sum \frac{\left(x-\overline{x_{i}}\right)^{2}}{n}}
$$

I specify uncertainty as the unknown variation in the dependent variable as a function of the model. Uncertainty for the experiment is estimated by the probability density function for a normal distribution where:

$$
p(x)=\frac{1}{\sigma \sqrt{2 \pi}} \exp \left(-\frac{(x-\mu)^{2}}{2 \sigma^{2}}\right)
$$

Where $\mu$ represents the mean and $\sigma$ is the standard de viation.

The term expdenotes an exponential function. From this, the probability density function can be reduced to the following form:

$$
p(x)=\frac{1}{\sqrt{2 \pi}} e-\frac{1}{2} x^{2}
$$

To model simulated effects of uncertainty on political campaigns, I will randomly create 10,000 separate elections for each district, and chamber, that utilizes random samples of the probability density function as it relates to model uncertainty. By creating repeated samples, I will be able to draw upon different sets of model uncertainty as a means to create a simulated sample of data that represents the true values of the data included in the original sample (Kennedy 2003). The expected value that will be generated by these estimations will simply be the average of 10,000 estimates which can be viewed as random drawings from the overall sample drawings of simulated elections. Thus the expected value of these estimates is computed as:

$$
\text { expected value }=\hat{\beta}=\left(\sum_{i=1}^{1,000} \hat{\beta}_{i}\right) \div 10,000
$$

The expected value will be estimated in two manners. The first will take the fixed effects of the observations of the test case and then adds the stochastic process which includes the error term and the random selection of Clean Election funding among candidates competing in legislative elections. Second, I will create estimators that are not fixed on a single point observation but rather mimic the normal data generating process for district level outcomes among Arizona, Maine, and New Jersey. To do this I will estimate the variance of the sampling distribution of the model's observations. This allows the analysis to simulate 
various conditions on electoral outcomes which do not deviate far from the true population variance (Kmenta 1986; Kennedy 2003).

The benefit of allowing variation among the observations included in the original sample is that it allows for values of the model's parameters to vary in a represented way over repeated samples. Doing this ensures the simulation is not sensitive to the characteristics of specific legislative elections included in the sample. The fixed estimates allow a comparative benchmark to the random estimates because the former is conditional on the observed sample of New Jersey's elections. For estimating the sample variance that will be used to allow variation in observations included in the sample, I define this process as:

$$
\text { estimated variance }=\sum_{i=1}^{10,00}\left(\hat{\beta}_{3 i}-\beta_{3}\right)^{2} \div 9,999
$$

Independent variables included in the general election model are:

1. District partisanship: This variable controls for the party that won the district and chamber during the previous election cycle. The variable is coded as " 1 " for a district coded by the Democratic Party and " 0 " for districts controlled by the Republican Party.

2. Average Primary Percent: This variable estimates the average party vote for the Republican and Democratic primary contests in a district for a given chamber prior to the general election.

3. Minority Party: This variable is coded as " 1 " for the party that is the minority party in the legislature from the previous election and " 0 " for the majority party.

4. Number of CE candidates: This variable is the total number of candidates running in a particular election who participate in CE funding.

5. District Incumbency: This variable estimates the number of incumbents running in a district for each chamber.

6. Number of Major Party Candidates: This variable is the total number of major party candidates running in a particular legislative election for each chamber.

7. Senate/House: This variable is coded as " 1 " for Senate races and " 0 " for lower house races.

8. Clean Elections: This variable is specified as " 1 " for all elections after 2000 and "0" for all other elections.

9. Difference in State-National Presidential Vote: This variable is specified as the difference of the State Democratic Vote for President from the National Vote for the Democratic presidential candidate. 
10. Competitive District: This variable is coded as " 1 " for districts that were competitive in the following election and " 0 " for all other districts.

11. Model Uncertainty: This variable includes all unexplained variation in the dependent variable.

For the primary model, the analysis will focus on whether Clean Elections impacts the number of candidates who contested a seat in a given primary. Similar to the general election model, I will estimate two equations, one for the Republican Party and the other for the Democratic Party, in order to estimate the number of major party candidates who choose to run in primary elections. Causality for this model argues that Clean Election funding facilities an increase in the number of candidates who choose to run for a given seat which in turn, causes an increase in intraparty competition. The independent variables used to estimate the two equations are:

1. Maine: A binary variable coded as " 1 " for Maine and " 0 " for Arizona.

2. Senate/House: This variable is coded as " 1 " for Senate races and " 0 " for lower house races.

3. Number of CE candidates: This variable is the total number of candidates running in a particular election who participate in CE funding.

12. District partisanship: This variable controls for the party that won the district and chamber during the previous election cycle. The variable is coded as " 1 " for a district coded by the Democratic Party and " 0 " for districts controlled by the Republican Party.

4. Average Primary Percent for Democratic and Republican Primaries: This variable estimates the average party vote in the primary contest prior to the general election.

5. Model Uncertainty: This variable includes all unexplained variation in the dependent variable.

\section{Results}

The first set of results summarize estimates from the two equations for legislative contests in Arizona and Maine from 1990-2006. Table 1 provides a summary of overall model fit of the GOP and Democratic Party estimates. The table also summarizes the model's parameters. From the results, both equations exceed their critical F-Test values (153 for the GOP equation and 123 for the Democratic equation). In addition the model explains roughly $58 \%$ of variation explained for the GOP estimates and approximately $50 \%$ of total variation explained for the Dem estimates. For the GOP equation, all of the parameters of the model reach statistical significance except for the number of major party candidates running in an election, the structural differences before and after the implementation of CE, Senate races, and the differences between the state and national vote for the Democratic Party's candidate for president. The level of uncertainty for the equation, as specified by the model's mean square error statistic, is approximately $\pm 16.13 \%$ of the total vote. 
Table 1: Equation estimates for Democratic and Republican Party percentage of the vote in Arizona and Maine-19902006

\begin{tabular}{|c|c|c|c|c|c|c|}
\hline 1229 & $\begin{array}{l}\text { F Test } \\
153.28\end{array}$ & $\begin{array}{c}\text { Sig. } \\
0\end{array}$ & $\begin{array}{c}\text { R-squared } \\
0.5843\end{array}$ & $\begin{array}{c}\text { Root MSE } \\
0.16134\end{array}$ & & \\
\hline Variables & Coef. & Std. Err & T Value & Sig. & Lower & Upper \\
\hline Minority Party & 0.13 & 0.01 & 10.58 & 0.00 & 0.11 & 0.16 \\
\hline Avg Primary Percent of Vote & 0.05 & 0.03 & 1.78 & 0.08 & -0.11 & 0.01 \\
\hline Number of CE Candidates & 0.01 & 0.00 & 2.75 & 0.01 & 0.00 & 0.02 \\
\hline District Incumbency & 0.02 & 0.01 & 1.82 & 0.07 & 0.00 & 0.04 \\
\hline District Party Control & 0.43 & 0.01 & 32.53 & 0.00 & -0.45 & -0.40 \\
\hline Number of Major Party Candidates & 0.00 & 0.01 & 0.09 & 0.93 & -0.02 & 0.03 \\
\hline Clean Elections & 0.01 & 0.02 & 0.61 & 0.54 & -0.02 & 0.04 \\
\hline Senate & 0.01 & 0.01 & 0.56 & 0.58 & -0.02 & 0.03 \\
\hline Diff (State Dem Pres Vt- Nat. Dem Pres Vt) & 0.00 & 0.00 & 1.60 & 0.11 & 0.00 & 0.01 \\
\hline Lagged District Competitiveness & 0.03 & 0.01 & 2.82 & 0.01 & 0.01 & 0.05 \\
\hline Constant & 0.19 & 0.05 & 3.97 & 0.00 & 0.10 & 0.28 \\
\hline \multicolumn{7}{|l|}{ D.V. Percent of GOP Vote } \\
\hline $\mathrm{N}$ & F Test & Prob > F & R-squared & Root MSE & & \\
\hline 1229 & 122.5 & 0 & 0.5026 & 0.17046 & & \\
\hline Variables & Coef. & Std. Err & T Value & Sig. & Lower & Upper \\
\hline Minority Party & -0.124 & 0.014 & -8.963 & 0.000 & -0.151 & -0.097 \\
\hline Avg Primary Percent of Vote & 0.233 & 0.052 & 4.452 & 0.000 & 0.130 & 0.335 \\
\hline Number of CE Candidates & -0.020 & 0.004 & -4.901 & 0.000 & -0.028 & -0.012 \\
\hline District Incumbency & -0.011 & 0.011 & -1.013 & 0.311 & -0.032 & 0.010 \\
\hline District Party Control & 0.389 & 0.016 & 24.075 & 0.000 & 0.358 & 0.421 \\
\hline Number of Major Party Candidates & 0.046 & 0.014 & 3.380 & 0.001 & 0.019 & 0.073 \\
\hline Clean Elections & -0.028 & 0.018 & -1.586 & 0.113 & -0.063 & 0.007 \\
\hline Senate & -0.002 & 0.013 & -0.149 & 0.882 & -0.028 & 0.024 \\
\hline Diff (State Dem Pres Vt- Nat. Dem Pres Vt) & -0.007 & 0.002 & -3.284 & 0.001 & -0.012 & -0.003 \\
\hline Lagged District Competitiveness & -0.027 & 0.011 & -2.458 & 0.014 & -0.048 & -0.005 \\
\hline Constant & 0.541 & 0.070 & 7.711 & 0.000 & 0.403 & 0.679 \\
\hline
\end{tabular}

D.V. Percent of Democratic Party Vote

Similar patterns persist in the Democratic equation. Again, all of the parameters reach statistical significance except for districts that have incumbents running for office, the structural differences before and after the implementation of $\mathrm{CE}$, and Senate races. Model uncertainty for the Democratic Party equation is approximately $\pm 17 \%$.

An important finding from both equations summarized in Table 1 is the variable that specifies before and after effects of Clean Elections at the district level is not significantly different from zero. The number of Clean Election candidates running in contests, however, is significant in both equations. The effects of Clean Elections appear to help the GOP share of the vote, while results indicate a decrease in the share of the Democratic Party's vote. A one unit change in the number of Clean Election candidates, other things being equal, yields a .01 increase in the percentage of the GOP's total vote in an election contest. For Democrats, a one-unit change in the number of Clean Election candidates competing in a contest results in a -.02 decrease in the Democratic Party's total percentage of the vote controlling for all other variables in the model. 
The variable that has the largest influence in explaining variation in the total percent of the vote for either party is whether or not the party had controlled a particular district from the previous election. For the GOP, it is expected to increase the percentage vote for the party by $43 \%$, other things being equal. For the Democratic Party, district party control results in an increase of approximately $39 \%$ controlling for all other variables in the model. In addition, the model finds differences in whether the Democrats or Republicans are the minority party in the legislature. Minority party status results in $12.4 \%$ decrease for the Democratic Party, controlling for all other variables. For the GOP, a 13\% increase is expected when the party is in the minority, other things being equal. To sum up, both equations exhibit stability in the parameters, as well as similar levels of uncertainty which can be applied to the New Jersey case.

From the simulated runs on New Jersey elections, Table 2 provides a summary of the mean and standard deviations of three estimates from the experiment. The first item is the original vote share for each party prior to running the simulations. This estimate provides a benchmark that can be compared to the effects of Clean Elections on electoral outcomes. The second estimate reports the fixed effects of Clean Election funding; for this estimate variation occurs in the level of uncertainty within each equation and the number of CE candidates. The benefit of using the fixed estimates is that it provides a framework in which to analyze the likely effects of Clean Election funding on New Jersey elections. The third provides some random variation across all of the observations for Arizona, Maine, and New Jersey. Random variation provides a means to estimate outcomes of the program's effects in states beyond those included in the sample. The last column in the table reports the probability of receiving a simple majority of the vote as a result of each estimate. 


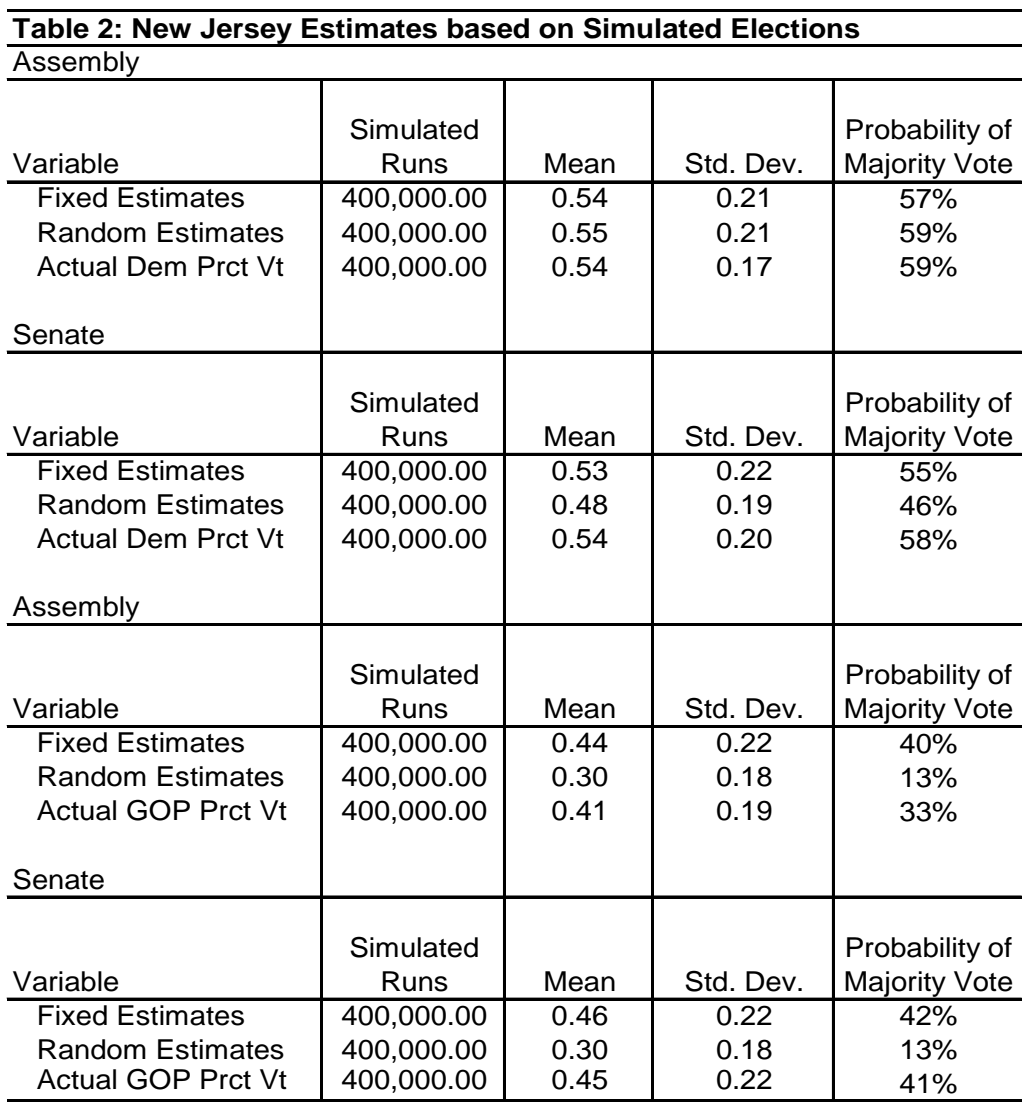

The results in Table 2 for the fixed estimates do not deviate far from the actual vote share for each party. On average, the fixed estimates indicate a 54\% share of the vote for the lower house, and 53\% of the vote in the upper house for the Democratic Party. The actual average vote share for the Democratic Party was 54\% in each chamber. Random estimates for the Democratic Party equation do demonstrate slight deviation from the norm when implementing Clean Elections more broadly. For the lower house, the expected vote share for the Democratic Party based on the randomized estimates results in 55\% of the vote for the lower house and $48 \%$ of the vote for the upper house.

For the Republican model, the fixed estimates approximate $44 \%$ of the vote for the lower house, and $46 \%$ of the vote in the upper house. The actual average vote share for the Republican Party was $41 \%$ of the vote in the lower house and $45 \%$ of the vote in the upper house. Random estimates indicate the party would do worse than what is expected in the fixed estimates. Moreover, the random simulated effects expect $30 \%$ of the share of the vote for the party for each chamber. 
Of further interest is understanding how the program influences the probability of either party winning a majority of the vote. The results of the fixed effects simulations indicate no changes in the probability of either party winning a majority of the vote as a result of CE. For Democrats, the probability of a lower house win $(57 \%)$ and for the upper house $(55 \%)$, based on the fixed effects model. This indicates a nominal change from the actual estimates; a lower house probability of $59 \%$ and for the upper house a probability of $58 \%$ of winning a majority of the vote.

For Republicans, the probability of a win in the lower house (40\%), based on the fixed effects model, is higher than the actual estimates which yield a $33 \%$ probability of winning the majority vote. For the upper house, the fixed effects model results in a negligible change in the probability (42\%) of winning the majority vote when compared to the actual estimates of a probability of $41 \%$. Nevertheless, the results of the general election analysis indicate that changes as a result of $\mathrm{CE}$ are not large enough to change the status quo. Likely reasons for this result is due to other traditional factors (e.g. partisanship, incumbency, intrainstitutional factors, etc.) continuing to play large roles in electoral outcomes at the state level.

Table 3 provides a summary of the model's results by district and chamber for general elections. Precisely it allows an analysis of whether the program's implementation would result in a change from the status quo at the state legislative district level. From these results, there is a high probability of the Democratic Party receiving a majority of the vote in lower house districts the party already controls. Overall the effects of Clean Election funding on Democrats, in districts the party already controls, can expect to receive about $65 \%$ of the total vote received; this increase is nominal because the party received an average of $63 \%$ of the vote in districts they controlled during the 2007 election.

In upper house races, the Democratic Party is expected, on average, to yield 64\% of the vote as a result of Clean Elections. This is a slight decrease from the 2007 average of $70 \%$ of the vote the party received in Senate races in districts the party controlled. Again, these results indicate that the implementation of Clean Elections does not cause substantial deviation in the likelihood of races becoming more competitive at the district level as a result of the program. 


\begin{tabular}{|c|c|c|c|c|c|c|c|c|c|c|c|c|}
\hline \multirow[b]{2}{*}{ Chamber } & \multirow[b]{2}{*}{ Distr } & \multirow[b]{2}{*}{\begin{tabular}{|l} 
Party \\
Control \\
\end{tabular}} & \multicolumn{5}{|c|}{ Repulican Party } & \multicolumn{5}{|c|}{ Democratic Party } \\
\hline & & & \begin{tabular}{|l} 
Fixed \\
Est. \\
\end{tabular} & \begin{tabular}{|l} 
Random \\
Est. \\
\end{tabular} & $\begin{array}{c}\text { Avg } \\
\text { GOP } \\
\text { Vt. }\end{array}$ & $\begin{array}{l}\text { Fixed } \\
\text { Prob. }\end{array}$ & \begin{tabular}{|l|} 
Random \\
Prob. \\
\end{tabular} & \begin{tabular}{|l} 
Fixed \\
Est.
\end{tabular} & \begin{tabular}{|l} 
Random \\
Est. \\
\end{tabular} & $\begin{array}{l}\text { Avg. } \\
\text { Dem. } \\
\text { Vt. } \\
\end{array}$ & $\begin{array}{l}\text { Fixed } \\
\text { Prob. } \\
\end{array}$ & $\begin{array}{l}\text { Random } \\
\text { Prob. }\end{array}$ \\
\hline $\mathrm{R}$ & 1 & D & $32 \%$ & $26 \%$ & $46 \%$ & $13 \%$ & $7 \%$ & $67 \%$ & $53 \%$ & $54 \%$ & $83 \%$ & $57 \%$ \\
\hline$S$ & 1 & D & $32 \%$ & $25 \%$ & $44 \%$ & $13 \%$ & $7 \%$ & $67 \%$ & $50 \%$ & $56 \%$ & $84 \%$ & $50 \%$ \\
\hline $\mathrm{R}$ & 2 & $\mathrm{R}$ & $61 \%$ & $36 \%$ & $57 \%$ & $75 \%$ & $21 \%$ & $41 \%$ & $44 \%$ & $43 \%$ & $29 \%$ & $38 \%$ \\
\hline $\mathrm{S}$ & 2 & D & $31 \%$ & $26 \%$ & $43 \%$ & $12 \%$ & $7 \%$ & $67 \%$ & $50 \%$ & $57 \%$ & $84 \%$ & $51 \%$ \\
\hline $\mathrm{R}$ & 3 & D & $31 \%$ & $25 \%$ & $38 \%$ & $12 \%$ & $7 \%$ & $68 \%$ & $54 \%$ & $59 \%$ & $85 \%$ & $59 \%$ \\
\hline $\mathrm{S}$ & 3 & D & $32 \%$ & $24 \%$ & $40 \%$ & $13 \%$ & $6 \%$ & $67 \%$ & $51 \%$ & $57 \%$ & $84 \%$ & $52 \%$ \\
\hline $\mathrm{R}$ & 4 & D & $31 \%$ & $26 \%$ & $45 \%$ & $12 \%$ & $7 \%$ & $67 \%$ & $54 \%$ & $55 \%$ & $84 \%$ & $58 \%$ \\
\hline $\mathrm{S}$ & 4 & D & $32 \%$ & $25 \%$ & $40 \%$ & $13 \%$ & $7 \%$ & $67 \%$ & $50 \%$ & $60 \%$ & $84 \%$ & $51 \%$ \\
\hline $\mathrm{R}$ & 5 & D & $32 \%$ & $25 \%$ & $34 \%$ & $12 \%$ & $6 \%$ & $67 \%$ & $54 \%$ & $61 \%$ & $84 \%$ & $58 \%$ \\
\hline $\mathrm{S}$ & 5 & D & $32 \%$ & $25 \%$ & $37 \%$ & $13 \%$ & $6 \%$ & $67 \%$ & $51 \%$ & $63 \%$ & $84 \%$ & $53 \%$ \\
\hline $\mathrm{R}$ & 6 & D & $31 \%$ & $26 \%$ & $40 \%$ & $12 \%$ & $7 \%$ & $68 \%$ & $53 \%$ & $56 \%$ & $85 \%$ & $57 \%$ \\
\hline$S$ & 6 & D & $32 \%$ & $25 \%$ & $38 \%$ & $13 \%$ & $6 \%$ & $67 \%$ & $51 \%$ & $62 \%$ & $83 \%$ & $52 \%$ \\
\hline $\mathrm{R}$ & 7 & D & $31 \%$ & $26 \%$ & $44 \%$ & $12 \%$ & $7 \%$ & $67 \%$ & $53 \%$ & $56 \%$ & $85 \%$ & $57 \%$ \\
\hline S & 7 & $\mathrm{R}$ & $61 \%$ & $35 \%$ & $56 \%$ & $76 \%$ & $20 \%$ & $40 \%$ & $41 \%$ & $44 \%$ & $29 \%$ & $31 \%$ \\
\hline $\mathrm{R}$ & 8 & $\mathrm{R}$ & $64 \%$ & $36 \%$ & $56 \%$ & $80 \%$ & $21 \%$ & $38 \%$ & $44 \%$ & $44 \%$ & $24 \%$ & $38 \%$ \\
\hline S & 8 & $\mathrm{R}$ & $62 \%$ & $35 \%$ & $61 \%$ & $77 \%$ & $20 \%$ & $40 \%$ & $42 \%$ & $39 \%$ & $29 \%$ & $34 \%$ \\
\hline $\mathrm{R}$ & 9 & $\mathrm{R}$ & $61 \%$ & $36 \%$ & $59 \%$ & $75 \%$ & $21 \%$ & $40 \%$ & $45 \%$ & $41 \%$ & $28 \%$ & $39 \%$ \\
\hline$S$ & 9 & R & $62 \%$ & $35 \%$ & $62 \%$ & $77 \%$ & $20 \%$ & $40 \%$ & $42 \%$ & $38 \%$ & $29 \%$ & $34 \%$ \\
\hline $\mathrm{R}$ & 10 & & $61 \%$ & $35 \%$ & $63 \%$ & $75 \%$ & $20 \%$ & $41 \%$ & $45 \%$ & $33 \%$ & $29 \%$ & $40 \%$ \\
\hline S & 10 & & $61 \%$ & $35 \%$ & $63 \%$ & $76 \%$ & $20 \%$ & $40 \%$ & $42 \%$ & $33 \%$ & $28 \%$ & $33 \%$ \\
\hline $\mathrm{R}$ & 11 & & $64 \%$ & $36 \%$ & $58 \%$ & $81 \%$ & $22 \%$ & $38 \%$ & $44 \%$ & $42 \%$ & $24 \%$ & $38 \%$ \\
\hline S & 11 & & $61 \%$ & $35 \%$ & $63 \%$ & $76 \%$ & $20 \%$ & $40 \%$ & $41 \%$ & $37 \%$ & $29 \%$ & $32 \%$ \\
\hline$R$ & 12 & & $64 \%$ & $36 \%$ & $51 \%$ & $81 \%$ & $21 \%$ & $38 \%$ & $45 \%$ & $49 \%$ & $24 \%$ & $39 \%$ \\
\hline S & 12 & & $62 \%$ & $35 \%$ & $54 \%$ & $76 \%$ & $21 \%$ & $40 \%$ & $41 \%$ & $46 \%$ & $29 \%$ & $32 \%$ \\
\hline $\mathrm{R}$ & 13 & & $64 \%$ & $36 \%$ & $57 \%$ & $81 \%$ & $21 \%$ & $38 \%$ & $44 \%$ & $43 \%$ & $25 \%$ & $38 \%$ \\
\hline$S$ & 13 & & $61 \%$ & $35 \%$ & $61 \%$ & $76 \%$ & $19 \%$ & $40 \%$ & $42 \%$ & $39 \%$ & $29 \%$ & $33 \%$ \\
\hline $\mathrm{R}$ & 14 & & $34 \%$ & $26 \%$ & $46 \%$ & $16 \%$ & $7 \%$ & $65 \%$ & $53 \%$ & $51 \%$ & $81 \%$ & $57 \%$ \\
\hline S & 14 & & $62 \%$ & $34 \%$ & $63 \%$ & $77 \%$ & $19 \%$ & $40 \%$ & $42 \%$ & $37 \%$ & $29 \%$ & $33 \%$ \\
\hline $\mathrm{R}$ & 15 & & $31 \%$ & $25 \%$ & $34 \%$ & $13 \%$ & $6 \%$ & $67 \%$ & $54 \%$ & $63 \%$ & $84 \%$ & $59 \%$ \\
\hline S & 15 & & $32 \%$ & $25 \%$ & $37 \%$ & $13 \%$ & $6 \%$ & $67 \%$ & $51 \%$ & $63 \%$ & $84 \%$ & $52 \%$ \\
\hline $\mathrm{R}$ & 16 & & $62 \%$ & $36 \%$ & $58 \%$ & $76 \%$ & $21 \%$ & $39 \%$ & $44 \%$ & $42 \%$ & $26 \%$ & $38 \%$ \\
\hline S & 16 & & $62 \%$ & $35 \%$ & $62 \%$ & $77 \%$ & $20 \%$ & $41 \%$ & $42 \%$ & $38 \%$ & $30 \%$ & $33 \%$ \\
\hline $\mathrm{R}$ & 17 & & $32 \%$ & $25 \%$ & $39 \%$ & $13 \%$ & $6 \%$ & $67 \%$ & $54 \%$ & $61 \%$ & $84 \%$ & $58 \%$ \\
\hline$S$ & 17 & & $62 \%$ & $35 \%$ & $62 \%$ & $76 \%$ & $20 \%$ & $40 \%$ & $42 \%$ & $38 \%$ & $28 \%$ & $34 \%$ \\
\hline $\mathrm{R}$ & 18 & & $32 \%$ & $25 \%$ & $43 \%$ & $13 \%$ & $6 \%$ & $67 \%$ & $53 \%$ & $57 \%$ & $84 \%$ & $57 \%$ \\
\hline S & 18 & & $32 \%$ & $25 \%$ & $38 \%$ & $13 \%$ & $6 \%$ & $67 \%$ & $51 \%$ & $62 \%$ & $84 \%$ & $52 \%$ \\
\hline . & 19 & & $31 \%$ & $25 \%$ & $40 \%$ & $13 \%$ & $6 \%$ & $67 \%$ & $54 \%$ & $60 \%$ & $85 \%$ & $58 \%$ \\
\hline$S$ & 19 & & $32 \%$ & $25 \%$ & $34 \%$ & $13 \%$ & $6 \%$ & $67 \%$ & $51 \%$ & $66 \%$ & $84 \%$ & $51 \%$ \\
\hline $\mathrm{R}$ & 20 & & $34 \%$ & $25 \%$ & $0 \%$ & $16 \%$ & $6 \%$ & $55 \%$ & $49 \%$ & $72 \%$ & $62 \%$ & $48 \%$ \\
\hline$S$ & 20 & & $32 \%$ & $24 \%$ & $16 \%$ & $13 \%$ & $6 \%$ & $67 \%$ & $51 \%$ & $59 \%$ & $84 \%$ & $52 \%$ \\
\hline$\pi$ & 21 & & $64 \%$ & $35 \%$ & $58 \%$ & $80 \%$ & $20 \%$ & $38 \%$ & $45 \%$ & $38 \%$ & $24 \%$ & $40 \%$ \\
\hline  & 21 & & $61 \%$ & $35 \%$ & $60 \%$ & $76 \%$ & $21 \%$ & $40 \%$ & $41 \%$ & $40 \%$ & $28 \%$ & $32 \%$ \\
\hline$\pi$ & 22 & & $31 \%$ & $25 \%$ & $21 \%$ & $12 \%$ & $6 \%$ & $67 \%$ & $54 \%$ & $70 \%$ & $84 \%$ & $59 \%$ \\
\hline 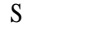 & 22 & D & $33 \%$ & $26 \%$ & $43 \%$ & $15 \%$ & $7 \%$ & $62 \%$ & $49 \%$ & $57 \%$ & $77 \%$ & $49 \%$ \\
\hline $\mathrm{R}$ & 23 & & $61 \%$ & $35 \%$ & $62 \%$ & $75 \%$ & $20 \%$ & $41 \%$ & $45 \%$ & $38 \%$ & $29 \%$ & $39 \%$ \\
\hline S & 23 & & $61 \%$ & $35 \%$ & $67 \%$ & $76 \%$ & $20 \%$ & $40 \%$ & $42 \%$ & $27 \%$ & $28 \%$ & $33 \%$ \\
\hline
\end{tabular}


For the Republican Party, running in districts controlled by the Democratic Party, the prospects of winning these districts based on Clean Elections are bleak. The overall average estimates for the Republican Party increase to $32 \%$ from $29 \%$ when factoring Clean Election funding into electoral contests in these districts. For Republicans running in Senate districts controlled by the Democratic Party, it is expected that the Republican vote in these districts would be $32 \%$; this is an increase of 4 percentage points from the party's actual vote share received in these districts during the 2007 elections.

The experiment yields similar patterns in Republican controlled Assembly districts when compared to lower house districts controlled by the Democrats. For Republicans, in lower house districts the party already controls, the party is likely to receive an average of $62 \%$ of the total vote when factoring in Clean Election funding. This increase, however, is only 2 percentage points higher than the average percent for the Republican Party in these districts during the 2007 election cycle.

For Democrats, running in Republican controlled districts, it is expected the party will receive an average of $39 \%$ of the total votes received in these districts after factoring in Clean Elections. This estimate does not substantial differ from the $40 \%$ share the party received during the 2007 election cycle.

For the Republican Party, running in Senate races in districts the party already controls, the results indicate patterns similar to the findings of upper house contests in districts controlled by Democrats. On average, it is expected the Republican Party will receive an average of $62 \%$ of the share of the vote in upper house races in these districts. It is important to note this result is not different from the status quo estimate which resulted in the party receiving an average estimate of $62 \%$ for Senate races in 2007 within these districts.

For the Democratic Party, running in Senate districts controlled by the Republican Party, the party can expect an average of $39 \%$ of the total vote share in these districts. Again, this estimate does not deviate from the $38 \%$ average the party received in Senate districts controlled by the Republicans during the 2007 election.

In addition, to evaluating the impact of Clean Elections on general elections, I have also conducted an analysis of the program's effects on primary contests. The primary model estimates the number of candidates running in primary contests. The dependent variable in this estimate serves as a function of whether or not the seat(s) was contested. The primary election results are summarized in Table 4.

Model fit for each equation reaches statistical significance; both equations exceed their critical values which are based on an F-distribution. For the Democratic model, the equation yields an F-test of approximately 390. In addition, 
approximately $74 \%$ of the variation in the number of candidates running in primary contests can be explained by the independent variables included in the model. The model has an error of approximately \pm .34 . All of the parameters included in the model achieve statistical significance.

Of particular importance for testing the causal model is, other things being equal, that an increase in the number of candidates participating in Clean Election funding increases the number of candidates running in a Democratic Party primary. More specifically, a .09 increase is expected in the number of candidates running for office based on a one-unit change in the number of candidates who participate in Clean Elections, controlling for all other variables in the model.

The Republican model had similar results. The F-test for this equation was roughly 627 . The model explains approximately $78 \%$ of the variation in the dependent variable. The model has an error of roughly \pm .39 . Again all of the equation's parameters achieve statistical significance. The effects of Clean Elections are positively associated with the number of Republican candidates running in primary contests. A one unit change in the number of candidates participating in Clean Election funding, other things being equal, yields a .13 increase in the number of candidates running in a Republican Party primary.



D.V. Number of Republican Candidates Running in Primary Elections 
After applying the equations summarized in Table 4 to New Jersey, the simulations provide some positive signs of the program's impact. The program would likely yield an increase in the number of candidates running for a seat for both parties. Table 5 provides a summary of the average estimates based on the simulation.

The results summarized in Table 5 indicate that on average, there is an expected increase in the number of candidates choosing to compete in a primary. This increase, however, is not likely to change the status quo in an increase of intraparty competition across the board. Broadly speaking, the fixed effects model does not indicate major changes in New Jersey as a result of the probability of a contested primary for Democrats in the lower house (approximately 16\%) and for Republicans (roughly 5\%). For Senate races, the outlook is similar. For Democrats running in upper house primaries, there is an $8 \%$ probability of the race being contested while for Republicans the probability is $11 \%$.

\begin{tabular}{|c|c|c|c|c|}
\hline Assembly & & & & \\
\hline Variable & $\begin{array}{l}\text { Simulated } \\
\text { Runs }\end{array}$ & Mean & Std. Dev. & $\begin{array}{l}\text { Probability of } \\
\text { Contested } \\
\text { Primary }\end{array}$ \\
\hline Fixed Estimates & 400,000 & 2.57 & 0.43 & $16 \%$ \\
\hline Random Estimates & 400,000 & 3.32 & 0.45 & $76 \%$ \\
\hline Actual Avg GOP Num Candidates & 400,000 & 2.28 & 0.44 & $5 \%$ \\
\hline Senate & & & & \\
\hline Variable & $\begin{array}{l}\text { Simulated } \\
\text { Runs }\end{array}$ & Mean & Std. Dev. & $\begin{array}{c}\text { Probability of } \\
\text { Contested } \\
\text { Primary } \\
\end{array}$ \\
\hline Fixed Estimates & 400,000 & 1.37 & 0.52 & $11 \%$ \\
\hline Random Estimates & 400,000 & 2.32 & 0.45 & $76 \%$ \\
\hline Actual Avg GOP Num Candidates & 400,000 & 1.19 & 0.27 & $0 \%$ \\
\hline Assembly & & & & \\
\hline Variable & $\begin{array}{l}\text { Simulated } \\
\text { Runs }\end{array}$ & Mean & Std. Dev. & $\begin{array}{c}\text { Probability of } \\
\text { Contested } \\
\text { Primary }\end{array}$ \\
\hline Fixed Estimates & 400,000 & 2.38 & 0.39 & $5 \%$ \\
\hline Random Estimates & 400,000 & 3.36 & 0.36 & $84 \%$ \\
\hline Actual Avg Dem Num Candidates & 400,000 & 2.34 & 0.54 & $11 \%$ \\
\hline Senate & & & & \\
\hline Variable & $\begin{array}{l}\text { Simulated } \\
\text { Runs }\end{array}$ & Mean & Std. Dev. & $\begin{array}{c}\text { Probability of } \\
\text { Contested } \\
\text { Primary } \\
\end{array}$ \\
\hline Fixed Estimates & 400,000 & 1.23 & 0.54 & $8 \%$ \\
\hline Random Estimates & 400,000 & 2.12 & 0.40 & $62 \%$ \\
\hline Actual Avg Dem Num Candidates & 400,000 & 1.22 & 0.47 & $5 \%$ \\
\hline
\end{tabular}


If the observations are allowed to randomly vary then significant changes are expected in an increase in the likelihood of the number of contested primary elections. Again, this is an encouraging sign of the program's positive impact. The simulation estimates better than chance odds of increased competition in primary contests when factoring in the effects of the program. For lower house races, the model expects an average probability of $84 \%$ that a primary election will be contested for Democrats; for Republicans the model expects an average probability of $76 \%$ that a lower house race will be contested. Similar results persist for upper house races. For Democrats running in Senate primaries, the model estimates an average probability of $62 \%$ the election will be contested. While for Republicans, the equation estimates an average probability of $76 \%$ that a Senate primary will be contested.

\section{Contextualizing the Experiment's Results: Where do we go from here?}

The New Jersey experiment provides an interesting test case of Clean Election funding. The uniqueness of this case provides an opportunity to add to what we currently know about Clean Elections in Arizona and Maine. Namely, a strong party system limits major swings in the seat distribution of either the upper house or lower house regardless of the effects of public campaign funding. The results yielded from the case indicate there are limitations of Clean Election funding; specifically its inability to make elections more competitive.

Moreover, what has been learned from the experiment is that Clean Election funding is unlikely to change the status quo in terms of party control of legislative districts. The simulations do, however, shed some light on marginal increases, or decreases, in the probability of either party winning or losing a particular district as a result of changes in the electoral environment that may be attributed to Clean Elections.

The experiment reveals the benefits of Clean Election funding on New Jersey are limited. First, from the experience in Arizona and Maine, New Jersey would likely benefit the minority party in terms of Clean Election funding. But this benefit is limited. For Republicans in New Jersey, an increase in the number of candidates participating in the program would have a positive, albeit nominal, effect on the party's overall performance. For Democrats, who are currently in the majority party, the program may in fact marginally affect their overall electoral performance. Yet the effects of Clean Elections on Democrats would not likely yield any major changes in the probability of whether they won or lost a district.

A benefit of the program's implementation is there are some indications of a likely rise in levels of intraparty competition. Clean Elections may in fact open up primary contests to increases in party challenges. The program may lower barriers for candidates, who are not the party establishment's choice, to run for public 
office. All of these outcomes would result in a positive impact of the program on the electoral environment as deemed by CE proponents.

To conclude, the simulation results indicate similar patterns to previous research conducted on Clean Election funding. Namely the effects of the program, on New Jersey state-legislative races, have a negligible impact on transforming the electoral landscape. Rather strong party structures dominant the political environment within the state dampening the effects of the program not only for the minority party, but also for third parties. A likely outcome of the implementation of this program is that it may further institutionalize the dominant parties within the current status quo. In addition, the effects of Clean Election funding may play a larger role in primary elections than is the case for general elections. Therefore the unintended consequences of the program, is that it is likely to create more intraparty competition rather than inter-party competition. Nevertheless additional research is required to test the program's effects not only in New Jersey, but also on other states contemplating the implementation of this program.

\section{Notes}

${ }^{1}$ For a comprehensive review of the impact of public funding in an international context, please refer to Simlov and Toplak (2008).

${ }^{2}$ For Arizona, Maine, and New Jersey the maximum individual contributions range from $\$ 100$ to $\$ 500$.

${ }^{3}$ For Maine and Arizona, this qualification requires that candidates receive a minimum of $\$ 5$ each from a minimum number of voters. For House races, 50 individuals must contribute in Maine and 220 in Arizona. The aggregate amount of funding for Maine is $\$ 220$ and for Arizona the total is $\$ 1,100$. For Senate races the total number of contributions from voters in Maine is 150 and for Arizona the number is the same as it is for the lower house. The total aggregate funds required in Maine for the upper house is $\$ 750$. For New Jersey the minimum contribution is $\$ 10$ each from a maximum of 800 voters for both chambers. A maximum of $\$ 8,000$ is required for both houses in New Jersey contests.

${ }^{4}$ For a full review of allocation formulas, please refer to Brickner and Mueller (2009).

${ }^{5}$ For instance research done in Slovenia, has found that political parties do in fact have a strong dependence on public subventions from the state; particularly for funding normal party operations. As a result, a strong dependence on state subventions of political parties' budgets has resulted in these parties becoming "cartel parties" (Toplak 2008: 183).

${ }^{6}$ A fuller discussion of the debate on state-level and political culture differences can be found elsewhere (e.g. , Elazar 1984; Berman, 1990; Potholm, 1996).

${ }^{7}$ An interesting difference from the Arizona and Maine policies is the wording that New Jersey used for the 2005 pilot project that focused less on claims that Clean Elections would level the playing field between candidates but rather its implementation would restore public trust in the election system (Brickner and Mueller 2008). 


\section{References}

Abramowitz, A. I., Alexander, B. \& Gunning, M. (2006) Incumbency, Redistricting, and the Decline of U.S. House Elections, The Journal of Politics, 68 (1), pp 75-88.

Adams, G. (2003) Publicly Funded Candidates Say They Will Use 'Clean' System Again, Associated Press Newswires (April 8).

Almond, G. A. \& Powell, g. B. (1978). Comparative Politics: System, Process, and Policy $\left(2^{\text {nd }} e d\right)$. (Boston: Little Brown).

Asher, A.(1985) Politics in Israel: The Second Generation (Chatham, N.J: Chatham House).

Bartels, L. M. (2002) Beyond the Running Tally: Partisan Bias in Political Perceptions, Political Behavior, 24 (2), pp. 117-150.

Basehart, H. \& Comer, J. (1991) Partisan and Incumbent Effects in State Legislative Redistricting, Legislative Studies Quarterly, 16 (1), pp. 65-79.

Berman, D. R. (1998) Arizona Politics and Government: the quest for autonomy, democracy, and development (Lincoln, NE: University of Nebraska Press)

Billeaud, J.( 2003) Commission Orders Three Candidates to Repay $\$ 104,000$, Associated Press Newswires (April 29).

Brewer, M. D. (2005) The Rise of Partisanship and the Expansion of Partisan Conflict within the American Electorate, Political Research Quarterly, 58 (2),. pp. 219-229.

Brickner, B. T. \& Mueller, N. (2008) Clean Elections Public Funding in Six States Including New Jersey's Pilot Programs (New Brunswick: the Eagleton Institute of Politics).

Campell, A., Converse, P., Miller , W. \& Stokes, D. (1960). The American Voter (New York: Wiley and Sons Inc.).

Carrier, P. (2003) Clean Elections' Law Popular but Needs Polishing, Portland Press Herald (February 21), p. A1.

Cassas-Zamora, K. (2002) Paying for Democracy in Latin America: Political Finance and State Funding for Parties in Costa Rica and Uruguay (Oxford: Department of Politics and International Re lations).

Center for Voting and Democracy. 2003. International Voter Turnout, 1991-2000 (http://www.fairvote.org/turnout/intturnout.htm, accessed June 23, 2003).

Cillizza, C. (2002) Under 55 Percent, Roll Call (November 14).

Daniels, E. (2001). Public financing: Making it work, League of Women Voters (June/July), pp. 8-13.

Downs, A. (1957). An Economic Theory of Democracy (New York: Harper Collins).

Duverger, M. (1955). Political Parties (London: Methuen).

Dye, T. R. (2001). Top Down Policymaking (New York: Seven Bridges).

Erikson, R. S. \& Wright, G. C. (2005) Voters, Candidates, and Issues in Congressional Elections, in Dodd, L. C \& Bruce I. O. (eds.) Congress Reconsidered, pp. 77-106.

Faucheux, R. \& Herrnson, P. (2000) Candidates Devote Substantial Time and Effort to Fundraising, Campaigns and Elections (www.bsos.umd.edu/gvpt/herrns on/reporttime.html, accessed June 20, 2003).

Faucheux, R. \& Herrnson, P. (1999a). State Legislative Candidates Favor Campaign Finance Reform, Campaigns and Elections (www.bsos.umd.edu/gvpt/herrns on/art2.html, accessed May 7, 2003).

Faucheux, R. \& Herrnson, P. (1999b). See How They Run: State Legis lative Candidates, Campaigns and Elections (www.bsos.umd.edu/gvpt/herrnson/art2.html, accessed May 7, 2003). 
Federal Election Commission (2002) 18 Month Financial Activity of Congressional Candidates (www.fec.gov/press/2002/0909canstats/cong18m92-02.html, accessed June 21, 2003).

Fiorina, M. P. (1991) Divided Government in the States, PS: Political Science and Politics, 24 (4), pp. 646-650.

Fiorina, M. P. (1977) An Outline for a Model of Party Choice, American Journal of Political Science, 21 (3), pp. 601-625.

Francia, P. L. \& Herrnson, P. S. (2003) The Impact of Public Finance Laws on Fundraising in State Legis lative Elections, American Politics Research, 31 (5), pp. 520-539.

Gedan, B. (2002) Massachusetts Clean Election System: Auction Revs Campaign Debate, Common Dreams News Center (April 29); also published in the Boston Globe (www.commonddreams.org/headlines02/0429-05.htm, accessed on June 30, 2003).

Gittell, S.( 2003) The Democratic Party Suicide Bill, The Atlantic Monthly, 292 (1), pp. 106-113.

Greene, W. H. (2003) Econometric Analysis, 5th ed. (New Jersey: Prentice Hall).

Griffin, J. (2006) Electoral Competition and Democratic Responsiveness: A Defense of the Margina lity Hypothesis, The Journal of Politics, 68 (4), pp 911-921.

Heard, A. (1960) The Costs of Democracy (Chapel Hill, North Carolina: University of North Carolina Press).

International Institute for Democracy and Electoral Assistance. 2003. Voter Turnout for Selected Countries. (http://www.idea.int/vt/country_view.cfm, accessed June 23, 2003).

Jacobson, G. (2008) The Politics of Congressional Elections, 5th Edition (New Jersey: Longman).

Johnson, C. A. (1976) Political Culture in American States: Elazar's Formulation Examined, American Journal of Political Science , 20 (3), pp. 491-509.

Johnston, M. (1983) Corruption and Political Culture in America: An Empirical Perspective, Publius, 13 (1), pp. 19-39.

Katz, R. S., Mair, P., Bardi, L., Bille, L., Deschouwer, K., Farrell, D., Koole, R., Morlino, L., Muller, W., Pierre, J., Poguntke, T., Sundberg, J., Svasand, L., Vandevelde, H., Webb, P. \& Widfeldt, A. (1992) The Membership of Political Parties in European Democracies, 1960-1990, European Journal of Political Research, 22 (3), pp.329-345.

Katz , R. S. \& Mair, P. (1995) Changing Models of Party Organization and Party Democracy: The Emergence of the Cartel Party, Party Politics , 1 (1), pp. 5-28.

Katz, R. S. (2002) The Internal Life of Parties, in: K.R. Luther, K. R. \& Muller-Romme1, F. (eds) Political Parties in the New Europe:Political and Analytical Challenges (Oxford: Oxford University Press), pp. 87-118.

Keller, A. (2003) Representative Flake Takes on Arizona Reform Law, Roll Call (March 6).

Kennedy, P. (1998). A Guide to Econometrics, 4th ed. (MA: The MIT Press).

Kmenta, J. (1997) Elements of Econometrics: Second Edition (AnnArbor: University of Michigan Press).

Koole, R. (2001) Political Finance in Western Europe: Britain and France, in: Nassmacher, K. H. (ed.) Foundations for Democracy, Approaches to Comparative Political Finance (Baden-Baden: Nomos Verlags gesellschaft), pp. 73-91.

Kousser, T. \& LaRaja, R. (2002) The Effect of Campaing Finance Laws on Electoral Competition: Evidence From the States, Policy Analysis , 426, pp. 1-10.

Lamprinakou, C. (2008) The Party Evolution Model: An Integrated Approach to Party Organization and Political Communication, Politics, 28 (1), pp. 3-11. 
Lees-Marshment, J. (2001) The Marriage of Politics and Marketing, Political Studies, 49 (4), pp. 692-713.

Lenox, S. (2007) Reauthorizing Clean Elections Vital to Reshaping Campaigns, The Trenton Times (March 28).

Lipset, S. M. (1981) Political Man: the Social Bases of Politics. $2^{\text {nd }}$.ed. (Baltimore: Johns Hopkins University Press).

Maine Citizen Leadership Fund (2003) Clean Elections at Work: The Second Cycle of Public Funding in Maine (April 3) (Portland, Maine: Maine Citizens for Clean Elections).

Maine Citizen Leadership Fund (2001) Clean Elections at Work: The Successful Debut of Maine's Public Funding System (June 13) (Portland, Maine: Maine Citizens for Clean Elections).

Mair, P. \& Van Birezen, I. (2001) Party Membership in Twenty European Democracies, 1980-2000, Party Politics, 7 (1), pp. 5-21.

Mann, T. E. (2003) Linking Knowledge and Action: Political Science and Campaign Finance Reform, Perspectives on Politics, 1 (1),pp. 69-83.

Mayer, K. R., Werner, T. \& Williams, A. (2004) Do Public Funding Programs Enhance Electoral Competition?, Paper presented at the Fourth Annual Conference on State Politics and Policy Laboratories of Democracy: Public Policy in the American States, Kent State University, April 30-May 1, 2004.

Mayer, K. R. \& Wood, J. M. (1995) The Impact of Public Financing on Electoral Competitiveness Evidence from Wisconsin, 1964-1990, Legislative Studies Quarterly, 20 (1), pp. 69-88.

Mendilow, J. (1992) Public Party Funding and Party Transformation in Multiparty Systems, Comparative Political Studies, 25 (1), pp. 90-117.

Mendilow, J. (1996) Public Funding and the Schemes of Mice and Men: The 1992 Elections in Israel, Party Politics, 2 (1), pp. 329-354.

Mendilow, J. \& Rusciano, F. L. (2001) The Effects of Public Funding on Party Participation, in: Nassmacher, K.H. (ed.), Foundations for Democracy Approaches to Comparative Political Finance (Baden-Baden: Nomos Verlagsgesellschaft), pp. 222239.

Meinke, S. R. \& Hasecke, E. B. (2003) Term Limits, Professionalization, and Partisan Control in U.S. State Legis latures, The Journal of Politics, 65 (3), pp. 898-908.

Milyo, J., Primo, D. \& Groseclose, T. (2002) The Effects of State Campaign Finance Regulation on Turnout, Electoral Competition, and Partisan Advantage in Gubernatorial Elections, 1949-1998, Paper presented at the American Political Science Association Annual Meeting, Boston, Massachusetts.

Morgan, D. R. \& Watson, S. S. (1991) Political Culture, Political System Characteristics, and Public Polic ies among the American States, Publius, 21 (2) , pp. 31-48.

Nassmacher, K. H. (1989) Structure and Impact of Public Subsidies to Political Parties in Europe: The Example of Austria, Italy, Sweden and West Germany; in: Herbert, A. (ed.) Political finance In the 1980s (Cambridge: Cambridge University Press), pp. 236267.

Nassmacher, K. H. (2001) Political Finance in West Central Europe, Austria, Germany, Switzerland; in: Nassmacher, K. H. (ed.) Foundations for Democracy Approaches to Comparative Political Finance (Baden-Baden: Nomos Verlagsgesellschaft), pp. 92111.

Nassmacher, H. \& Nassmacher, K. H. (2001) Major Impacts of Political Finance Regimes; in Nassmacher, K. H. (ed.) Foundations for Democracy Approaches to Comparative Political Finance (Baden-Baden: Nomos Verlagsgesellschaft), pp. 181-196. 
Niemi, R. G., Jackman, S. \& Winsky, L. R. (1991) Candidacies and Competitiveness in Multimember Districts, Legislative Studies Quarterly, 16 (1), pp. 91-109.

Oliver, J. Eric and Ha, Shang E. 2007. "Vote Choice in Suburban Elections", American Political Science Review, Vol. 101, No. 3, pp. 393-408.

Paltiel, K.(1980) Public Financing Abroad: Contrasts and Effects; in Malbin, M. J. (ed.), Parties, Interest Groups and Campaign Finance Laws (Washington, DC: American Enterprise Institue), pp. 138-172.

Paltiel, K. (1979) The Impact of Election Expenses Legis lation in Canada, Western Europe, and Israel; in: Alexander, H. (ed.) Political Finance (Beverly Hills, California: Sage), pp. 15-39.

Personen, P. (1987) The Impact of Public Financing of Political Parties: The Finnish Experience, Paper presented at the Conference of the Research Committee on Political Finance and Political Corruption, Bellagio, Italy.

Rebovich , D. (2007). The NJL column, 21 April.

Reznulli, D. (2002) Capitol Offenders: How Private Interests Govern Our States (Washington, D.C.: Public Integrity).

Salowe-Kaye, P. (2007) Get N.J's Stain out with Clean Elections, The Trenton Times, February 23.

Smilov, D. \& Toplak, J. (2007) Political finance and corruption in Eastern Europe: The Transition Period (Hampshire, England: Ashgate).

Scammell, M. (1999) Political Marketing: Lessons for Political Science, Political Studies, 47 (4), pp. 718-739.

Stratmann, T. \& A paricio-Castillo, F. Nd. Competition Policy for Elections: Do Campaign Contribution Limits Matter?, Unpublis hed manuscript.

Tabachnik, B. G. \& Fidell, L. S. (1989) Using Multivariate Statistics , $2^{\text {nd }}$. ed. (New York: Harper and Collins).

Tapley, L. (2001) Revolution in the Race for Governor, The Portland Phoenix, March 8-15.

Thompson, J. A., Cassie, W. \& Jewell, M. E. (1994) A Sacred Cow or Just a Lot of Bull? Party and PAC Money in State Legis lative Elections, Political Research Quarterly, 47 (1), pp. 223-237.

Toplak, J. (2007) Party Funding in Slovenia; in Smilov, D. \& Toplak, J. (eds.) Political finance and corruption in Eastern Europe: The Transition Period (Ashgate: Hampshire, England). pp. 171-188.

U.S. General Accounting Office. 2003. Campaign Finance Reform: Early Experiences of Two States That Offer Full Public Funding for Political Candidates (GAO-03-453) (Washington, DC: GPO).

Van Biezen, I. (2002) Limits to Public Funding: Political Finance in New Democracies, Paper presented at the American Political Science Association Annual Meeting, Boston, Massachusetts (August 29-September 1).

Walker, A. (2003) Clean Break from the Law, Boston Globe, June 2 , p. B-1.

Werner, T. \& Mayer, K. (2007) Public Election Funding, Competition, and Candidate Gender, PS: Political Science and Politics, 40 (4), pp. 661-667.

Wirt, F. M. (1991) "Soft" Concepts and "Hard" Data: A Research Review of Elazar's Political Culture, Publius, 21 (2), pp. 1-13.

Wyatt, B. (2002) The Origins of State Public Funding of Elections. Honors Thesis (Middletown: Wesleyan University) (www.octoernight.com/bwyatt/index.htm). 